\title{
Shelf life of composite flour mixtures
}

\author{
Ivan Kechkin ${ }^{1 *}$, Vladimir Ermolaev ${ }^{2}$,Elena Gurkovskaya $^{3}$, Irina Glebova $^{3}$, Marina Yakovchenko ${ }^{4}$, Dmitriy Fedorov $^{4}$ \\ ${ }^{1}$ All-Russian Scientific and Research Institute for Grain and Products of its Processing - Branch of V.M. Gorbatov Federal Research \\ Center for Food Systems of RAS, 11, Dmitrovskoye Shosse, Moscow, 127434, Russia \\ ${ }^{2}$ Department of Commodity Science and Expertise, Plekhanov Russian University of Economics, 36, Stremyanny Lane, Moscow, \\ 117997, Russia \\ ${ }^{3}$ K.G. Razumovsky Moscow State University of technologies and management (the First Cossack University), 73, Zemlyanyi Val str., \\ Moscow, 109004, Russia \\ ${ }^{4}$ Kuzbass State Agricultural Academy, 5, Markovtsev Str., Kemerovo, 650056, Russia
}

\begin{abstract}
Enrichment of food products with proteins, minerals and dietary fiber is possible by introducing grinding products of some cereal crops into wheat flour, i.e. obtaining composite flour mixtures. To date, there is a need to enrich food products with essential fatty acids, especially Linolenic acid (w-3), the deficiency of which leads to serious disruptions in functioning of the human body. Analysis of the lipid composition of various oilseed crops shows that the composition of flaxseed oil as a source of w-3 demonstrates an absolute advantage. The solution to the problem of flour enrichment with essential fatty acids is currently being solved by using crushed flaxseed cake. However, the use of flaxseed cake has several disadvantages. First of all, as studies have shown, the amount of such flaxseed flour in the composition of the composite mixture should be $15-20 \%$ to ensure the required amount in essential fatty acids, which significantly impairs the consumer properties of bread. The use of flax seeds directly will significantly reduce their proportion in the composition of the composite mixture.
\end{abstract}

\section{Introduction}

Grinding flax seeds with a fat content of less than $30 \%$ for the subsequent enrichment of wheat flour presents significant difficulties and is practically impossible to carry out in existing flour mills.

Thus, a rational solution for obtaining bakery flour enriched with essential fatty acids is to develop a technology for grinding a grain mixture, which should contain flax seeds.

The amount of secondary raw materials formed during the grain processing at flour mills is on average $21.3 \%$ of the total volume of flour production. One of the directions to integrate processing of the main grain raw material into processing of secondary products is biotransformation of the former, aimed at obtaining products with structurally modified biopolymers with desired functional and technological properties.

The wide range of the raw material base including grain, leguminous crops and by-products of their processing allows researchers to speak about the possibility and necessity of their use to create products based on directed biocatalysis, which have not only increased nutritional and biological value, but also a given composition as well as given functional and technological properties.

\section{Experimental section}

The results of comparative grinding of wheat grain (grinding 1) and wheat-flax mixture (grinding 2) are presented in Tables 1 and 2. Flour quality indicators are presented in Table 3.

The flour samples were stored in the laboratory at room temperature.

Quality indicators controlled during the storage period are presented in Table 4.

The initial value of the fat acidity value of wheat flour stored for preserving was $14.7 \mathrm{mg} \mathrm{KOH}$ per $1 \mathrm{~g}$ of fat, which indicates its high organoleptic characteristics. Wheat-flax flour has lower values of the fat acidity value, which is associated with low values of the fat acidity value of oilseeds compared to cereals. For flax seeds, the fat acidity value varies in the range of 0.55 3.5 ; as for edible flax, the fat acidity value should not exceed 2.0

The data obtained indicate an almost linear dependence of the fat acidity value increase within 6 months; at the same time, for 6 months of storage, the fat acidity value of wheat flour increased 2.3 times; and for wheat-flax flour - 3.1 times. The relative increase in the fat acidity value for wheat flour was $129 \%$; for wheat and flax flour - 214\% (Figure 1).

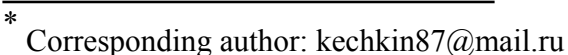


Table 1. Mass balances of the first wheat processing (Control).

\begin{tabular}{|l|l|l|l|l|l|l|l|l|}
\hline \multicolumn{1}{|c|}{ system } & load & 2-break & 3-break & scratch & grinding & \multicolumn{1}{c|}{1 reduction } & \multicolumn{1}{c|}{ flour } & bran \\
\hline 1-break & 100,0 & 38,7 & & & 23,3 & 20,5 & 17,5 & \\
\hline 2-break & 38,7 & & 21,6 & & 2,3 & 10,1 & 4,7 & \\
\hline 3-break & 21,6 & & & 4,4 & & 0,6 & 3,1 & 13,5 \\
\hline$\sum$ break systems & & & & 4,4 & 25,6 & 31,2 & 25,3 & 13,5 \\
\hline grinding & 25,6 & & & 7,2 & & 10,8 & 7,6 & \\
\hline $1-3$ reduction & 42,0 & & & 1,6 & & & 40,4 & \\
\hline scratch & 13,2 & & & & & & 1,6 & 11,6 \\
\hline$\sum$ reduction systems & & & & 8,8 & & 10,8 & 49,6 & 11,6 \\
\hline Total & & & & 13,2 & 25,6 & 42,0 & 74,9 & 25,1 \\
\hline
\end{tabular}

Table 2. Mass balances of processing the mixture of $93 \%$ wheat $+7 \%$ flax (\%) Grind 2

\begin{tabular}{|l|l|l|l|l|l|l|l|l|}
\hline \multicolumn{1}{|c|}{ system } & load & 2-break & 3-break & scratch & grinding & \multicolumn{1}{c|}{1 -3 reduction } & \multicolumn{1}{c|}{ flour } & bran \\
\hline 1-break & 100,0 & 41,0 & & & 22,2 & 22,0 & 14,8 & \\
\hline 2-break & 41,0 & & 25,7 & & 1,9 & 9,4 & 4,0 & \\
\hline 3-break & 25,7 & & & 7,4 & & 0,8 & 3,2 & 14,3 \\
\hline$\sum$ break systems & & & & 7,4 & 24,1 & 32,2 & 22,0 & 14,3 \\
\hline grinding & 24,1 & & & 6,2 & & 12,5 & 5,4 & \\
\hline 1-3 reduction & 44,7 & & & 2,7 & & & 42,0 & \\
\hline scratch & 16,3 & & & & & & 4,4 & 11,9 \\
\hline$\sum$ reduction systems & & & & 8,9 & & 12,5 & 51,8 & 11,9 \\
\hline Total & & & & 16,3 & 24,1 & 44,7 & 73,8 & 26,2 \\
\hline
\end{tabular}

Table 3. Quality indicators of the flour obtained from Grind 1 (Control) and Grind 2.

\begin{tabular}{|c|c|c|c|c|c|c|c|c|c|c|}
\hline \multirow{2}{*}{$\begin{array}{c}\text { Grinds/ } \\
\text { Quality } \\
\text { indicators }\end{array}$} & \multirow{2}{*}{$\begin{array}{l}\text { White- } \\
\text { ness, } \\
\text { units } \\
\end{array}$} & \multirow{2}{*}{$\begin{array}{c}\text { Humidit } \\
\mathrm{y}, \\
\%\end{array}$} & \multirow{2}{*}{$\begin{array}{c}\text { Ash } \\
\text { content, } \\
\%\end{array}$} & \multirow{2}{*}{$\begin{array}{c}\text { Protein, } \\
\%\end{array}$} & \multirow{2}{*}{$\begin{array}{l}\text { Fat, } \\
\%\end{array}$} & \multicolumn{2}{|c|}{ Grant composition, gr } & \multicolumn{3}{|c|}{ Gluten } \\
\hline & & & & & & & & Quantity, \% & $\begin{array}{l}\text { GDI, } \\
\text { units }\end{array}$ & $\begin{array}{l}\text { Dryness, } \\
\%\end{array}$ \\
\hline \multirow[t]{3}{*}{$\begin{array}{l}\text { Wheat flour- } \\
\text { Grind } 1\end{array}$} & \multirow[t]{3}{*}{52,4} & \multirow[t]{3}{*}{13,9} & \multirow[t]{3}{*}{0,56} & \multirow[t]{3}{*}{13,48} & \multirow[t]{3}{*}{1,7} & $\begin{array}{l}\text { Remaining on } \\
\text { the sieve } 180\end{array}$ & 0,15 & \multirow{3}{*}{$\begin{array}{c}\text { P.28,24 } \\
\text { (mechaniz } \\
\text { ed gluten } \\
\text { washing) } \\
29,08\end{array}$} & \multirow{3}{*}{$\begin{array}{l}62,0 \\
67,0\end{array}$} & \multirow{3}{*}{$\begin{array}{l}10,04 \\
10,72\end{array}$} \\
\hline & & & & & & $\begin{array}{l}\text { Remaining on } \\
\text { the sieve } 140\end{array}$ & 0,29 & & & \\
\hline & & & & & & $\begin{array}{c}\text { Passage } \\
\text { through the } \\
\text { sieve } 140\end{array}$ & 99,31 & & & \\
\hline \multirow{3}{*}{$\begin{array}{l}\text { Flour } \\
\text { wheat }+ \text { flax } \\
- \text { Grind } 2\end{array}$} & \multirow[t]{3}{*}{43,6} & \multirow[t]{3}{*}{13,0} & \multirow[t]{3}{*}{0,64} & \multirow[t]{3}{*}{13,77} & \multirow[t]{3}{*}{3,9} & $\begin{array}{l}\text { Remaining on } \\
\text { the sieve } 180\end{array}$ & 0,03 & \multirow[t]{3}{*}{$\begin{array}{c}\text { P1 29 } \\
\text { P2 28,84 }\end{array}$} & \multirow{3}{*}{$\begin{array}{c}65 \\
67,9\end{array}$} & \multirow{3}{*}{$\begin{array}{l}9,68 \\
9,60\end{array}$} \\
\hline & & & & & & $\begin{array}{l}\text { Remaining on } \\
\text { the sieve } 140\end{array}$ & 0,62 & & & \\
\hline & & & & & & $\begin{array}{c}\text { Passage } \\
\text { through the } \\
\text { sieve } 140\end{array}$ & 99,12 & & & \\
\hline
\end{tabular}

Table 4. Quality indicators of flour samples during the storage period.

\begin{tabular}{|l|c|c|c|}
\hline \multicolumn{1}{|c|}{ Samples } & $\begin{array}{c}\text { Protein (N 6.25), } \\
\text { GOST 10846-91 }\end{array}$ & $\begin{array}{c}\text { Fat, \% } \\
\text { GOST 29033-91 }\end{array}$ & $\begin{array}{c}\text { Fat acidity value, } \\
\text { mg KOH/g GOST 31700-2012 }\end{array}$ \\
\hline \multicolumn{4}{|c|}{ For the period of 26.02-10.03.2020 } \\
\hline Wheat flour & 13,48 & 1,7 & $14,7 \pm 1,5$ \\
\hline Wheat-flax flour & 13,77 & 3,9 & $8,5 \pm 0,8$ \\
\hline
\end{tabular}




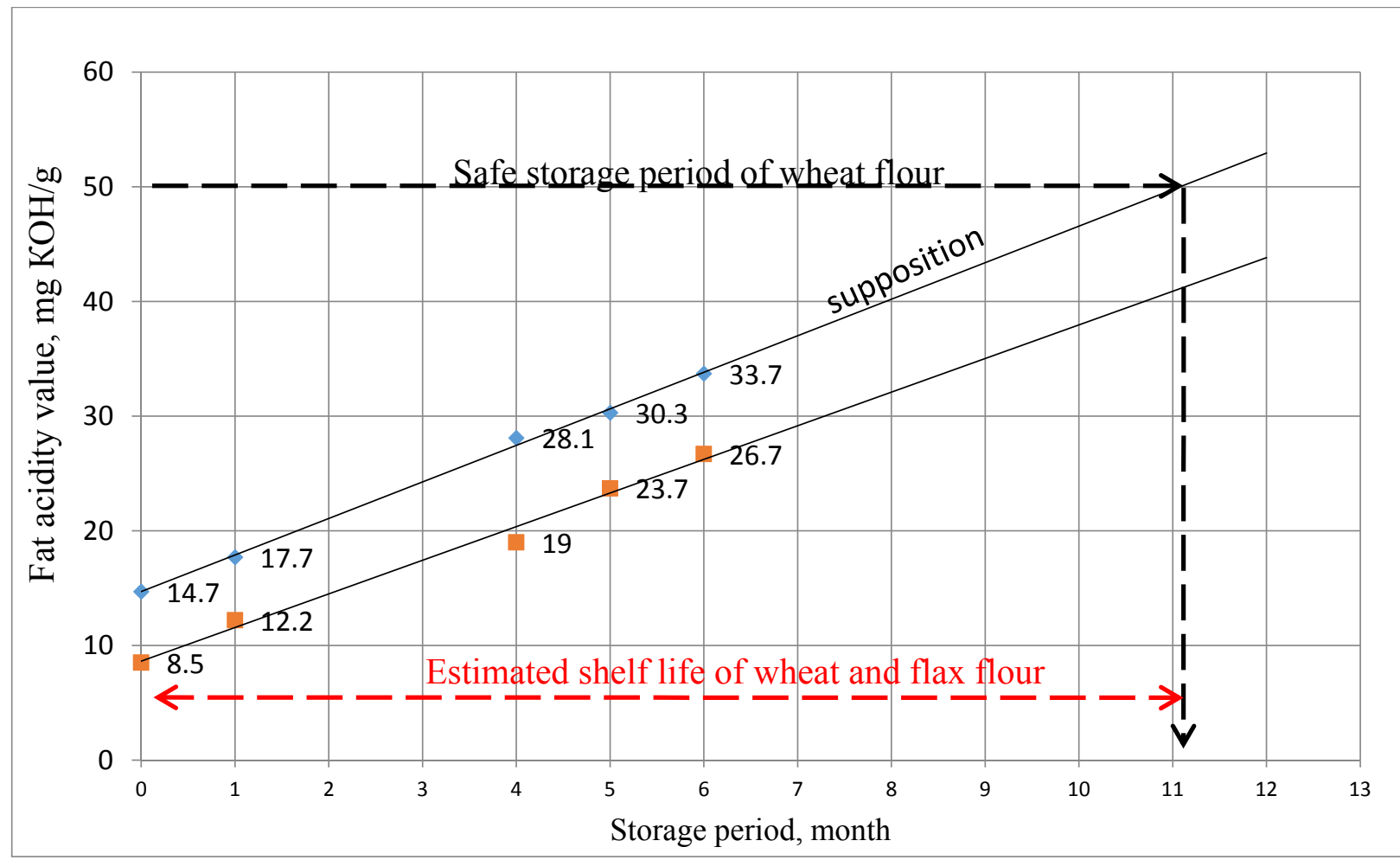

Figure 1. Diagram of changes in the fat acidity value of wheat and wheat-flax flour.

The basic trend for premium wheat flour is a linear dependence of the change in the fat acidity value along the shelf life period in this range. Therefore, the prediction of reaching the safe storage rate $(50 \mathrm{mg} \mathrm{KOH}$ per $1 \mathrm{~g}$ of fat) for wheat flour under the same storage conditions is $\sim 11$ months. The nature of the change in fat acidity value in terms of storage time for wheat-flax flour practically does not differ from the one of the wheat flour.

The estimated predicted safe shelf life of wheatflaxseed flour is 11 months $\times 0.85=9.4$ months, if the product organoleptic characteristics meet standard requirements.

\subsection{An alternative way of producing wheat-flax flour}

The introduction of flax seeds into the grain mixture leads to a darkening of the bread crumb, especially for flour grade B (Figure 2).

The main disadvantage of multi-grade grind is the uneven distribution of fat among flour grades. To eliminate this drawback, it was proposed to use processed products - cereals instead of wheat grain. This allows conducting the single-grade grind according to a simple scheme taking into account a predetermined chemical composition of the flour.

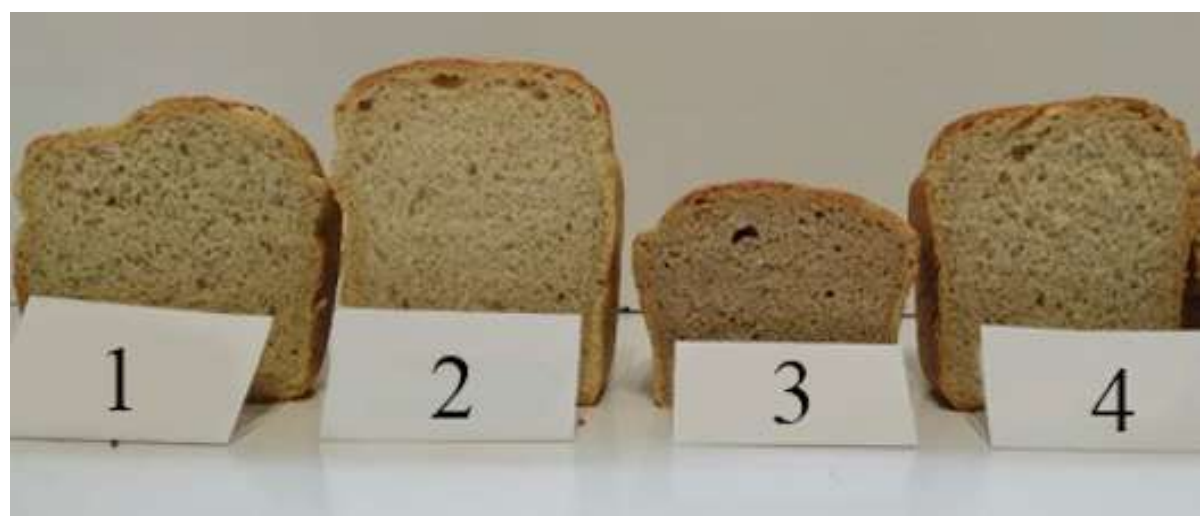

Figure 2. Bread made from wheat-flax flour of different grades: 1 - Control (wheat flour); 2 - wheat-flax flour, grade A; 3 - wheatflax flour, grade B; 4 - wheat-flax flour, grade C.

\section{Results}

In the course of the research, a scheme for processing mixtures consisting of various cereals and flax seeds was developed. A mixture of various wheat middlings and flax seeds was ground according to the scheme presented in Figure 3.

Mass balance data are given in Tables 5 and 6.

Experimental laboratory baking of bread and its assessment was carried out in accordance with GOST 
27669-88 "Wheat baking flour. The method of testing laboratory baking of bread".

The organoleptic assessment of the baked bread was carried out according to the following indicators:
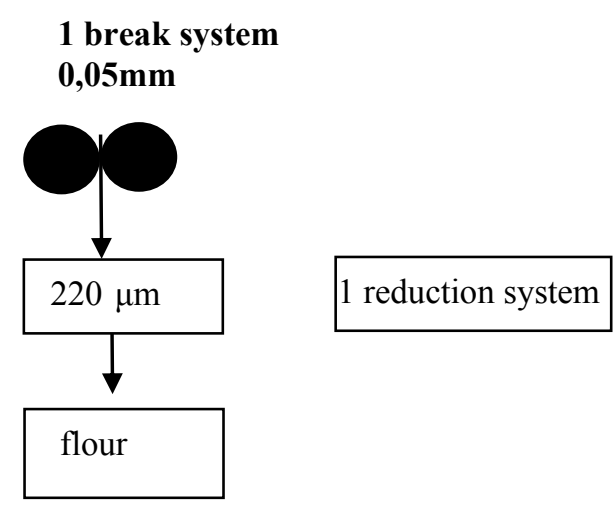

\section{1 reduction system $0,01 \mathrm{~mm}$}

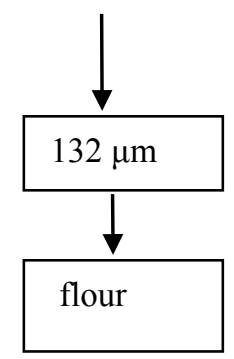

the appearance of the bread (shape, condition of the crust surface); crust color; crumb condition: color, color uniformity, elasticity; porosity: size, uniformity, thickness of the pore walls; taste, crunch and crumbling.

\section{2 break system $0,01 \mathrm{~mm}$}

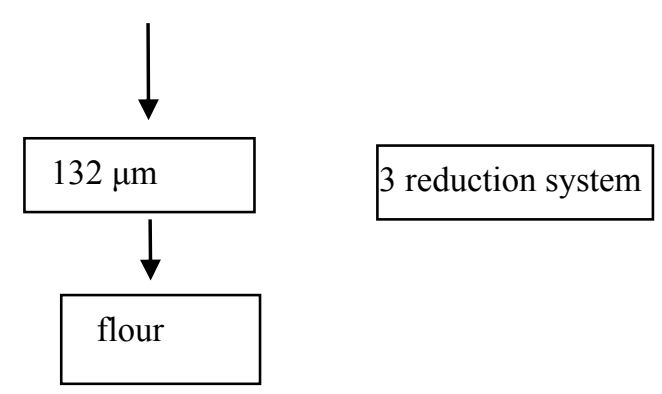

3 reduction system

$0,01 \mathrm{~mm}$

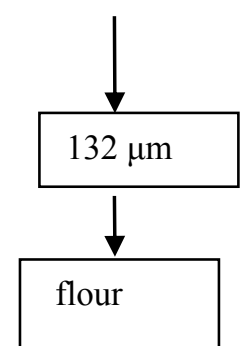

bran

Figure 3. Alternative scheme of processing binary mixtures

Table 5. Mass balance (\%). Grind 3.

\begin{tabular}{|l|l|l|l|l|}
\hline System & Load & $1-3$ reduction systems & Flour & Bran \\
\hline Break system & 100 & 44,0 & 56,0 & \\
\hline $1-3$ reduction systems & 44,0 & & 44,0 & \\
\hline Total & & & 100,0 & \\
\hline
\end{tabular}

Table 6. Mass balance (\%). Grind 4.

\begin{tabular}{|l|l|l|l|l|}
\hline System & Load & $1-3$ reduction systems & Flour & Bran \\
\hline Break system & 100,0 & 40,6 & 59,4 & \\
\hline $1-3$ reduction systems & 40,6 & & 23,7 & 16,9 \\
\hline Total & & & 83,1 & 16,9 \\
\hline
\end{tabular}

Table 7. Quality indicators of the flour obtained from the Grind 3 - semolina $(T$ and $M)+$ flax.

\begin{tabular}{|c|c|c|c|c|c|c|c|c|}
\hline \multirow{2}{*}{$\begin{array}{c}\text { Grinds/ } \\
\text { Quality indicators }\end{array}$} & \multirow{2}{*}{$\begin{array}{l}\text { Whiteness, } \\
\text { units }\end{array}$} & \multirow{2}{*}{$\begin{array}{c}\text { Humidity, } \\
\%\end{array}$} & \multirow{2}{*}{$\begin{array}{c}\text { Ash } \\
\text { content, } \\
\%\end{array}$} & \multicolumn{2}{|c|}{ Grant composition, gr } & \multicolumn{3}{|c|}{ Glutten } \\
\hline & & & & & & $\begin{array}{c}\text { Quantity, } \\
\%\end{array}$ & $\begin{array}{l}\text { GDI, } \\
\text { units }\end{array}$ & $\begin{array}{c}\text { Dryness, } \\
\%\end{array}$ \\
\hline \multirow{3}{*}{$\begin{array}{l}\text { Wheat flour from } \\
\text { wheat middling }+ \\
\text { flax } \\
\text { G-4 } \\
\text { dated } 17.02 .2020\end{array}$} & \multirow[t]{3}{*}{32,0} & \multirow[t]{3}{*}{11,0} & \multirow[t]{3}{*}{0,82} & $\begin{array}{l}\text { Remaining on } \\
\text { the sieve } 180\end{array}$ & 0,10 & 19,36 & 12 & 8,72 \\
\hline & & & & $\begin{array}{l}\text { Remaining on } \\
\text { the sieve } 140\end{array}$ & 6,67 & \multirow{2}{*}{\multicolumn{3}{|c|}{$\begin{array}{l}\text { Spongy, bad collecting, } \\
\text { crumbling. }\end{array}$}} \\
\hline & & & & $\begin{array}{l}\text { Passage through } \\
\text { the sieve } 140\end{array}$ & 93,03 & & & \\
\hline \multirow{3}{*}{$\begin{array}{l}\text { Flour from Semolina } \\
+ \text { flax } \\
\text { G-3 } \\
\text { date } 25.02 .2020\end{array}$} & \multirow[t]{3}{*}{38,1} & \multirow[t]{3}{*}{12,8} & \multirow[t]{3}{*}{0,55} & $\begin{array}{l}\text { Remaining on } \\
\text { the sieve } 180\end{array}$ & 1,61 & \multirow[t]{3}{*}{23,2} & \multirow[t]{3}{*}{50,3} & \multirow[t]{3}{*}{8,4} \\
\hline & & & & $\begin{array}{l}\text { Remaining on } \\
\text { the sieve } 140\end{array}$ & 18,60 & & & \\
\hline & & & & $\begin{array}{l}\text { Passage through } \\
\text { the sieve } 140\end{array}$ & 79,31 & & & \\
\hline
\end{tabular}




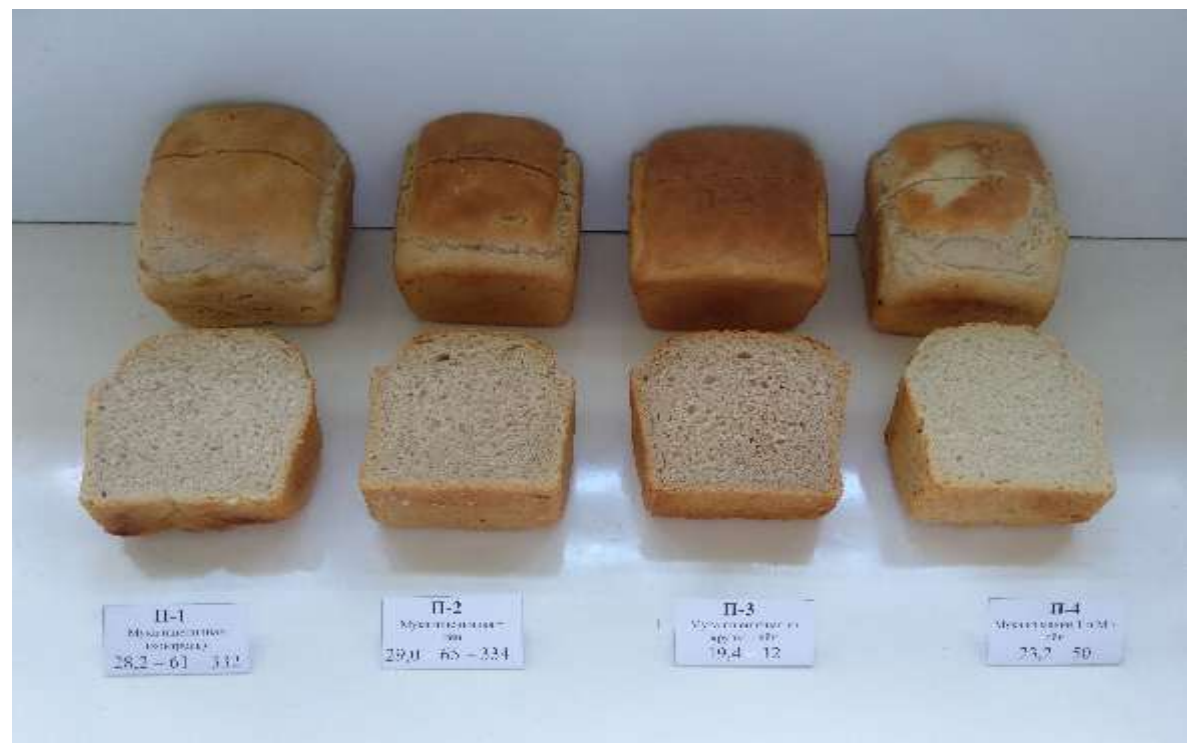

Figure 4. Bread from wheat and flax flour of different grades: G1 - control (wheat flour); G2 - wheat and flax flour; G3 - wheat and flax flour from middling; G4 - flour from semolina with flax.

The analyzed bread samples (Table 8) had a regular semi-oval shape, a smooth even surface of the crust (G3, G-4), an uneven bumpy surface (G-1, G-2); two samples (G-1, G-2) had small disruptions of the crust, sample (G-4) had disruptions of more than $1 \mathrm{~cm}$ on three sides of the bread. The color of the crust in samples (G-1 and G-2) was light brown, brown in the sample (G-3) and yellow at the sample (G-4).

Table 8. Quality characteristics of bread baked from G1-G4

\begin{tabular}{|c|c|c|c|c|c|c|c|}
\hline \multirow[t]{2}{*}{ № } & \multirow[t]{2}{*}{ Sample code } & \multirow{2}{*}{$\begin{array}{c}\text { Volume yield of } \\
\text { bread, } \mathrm{V}, \mathrm{cm}^{3} / 100 \mathrm{~g} \\
\text { of flour }\end{array}$} & \multirow{2}{*}{$\begin{array}{l}\text { Specific } \\
\text { volume }\end{array}$} & \multirow{2}{*}{$\begin{array}{l}\text { Porosity, } \\
\%\end{array}$} & \multicolumn{3}{|c|}{ Organoleptic assessment, score: } \\
\hline & & & & & appearance & crumb & total score \\
\hline 1 & 2 & 3 & 4 & 5 & 6 & 7 & 8 \\
\hline 1 & $\begin{array}{l}\mathbf{G}-\mathbf{1} \\
\text { (wheat flour - control) }\end{array}$ & 449 & 3,44 & 78 & 3 & 4 & 7 \\
\hline 2 & $\begin{array}{l}\mathbf{G - 2} \\
\text { (wheat flour - flax) }\end{array}$ & 422 & 3,30 & 79 & 3 & 3 & 6 \\
\hline 3 & $\begin{array}{l}\mathbf{G}-\mathbf{3} \\
\text { (wheat flour from middlings } \\
+ \text { flax) }\end{array}$ & 449 & 3,40 & 81 & 3 & 3 & 6 \\
\hline 4 & $\begin{array}{l}\mathbf{G}-\mathbf{4} \\
\text { (flour from semolina }+ \text { flax })\end{array}$ & 433 & 3,25 & 74 & 2,5 & 4 & 6,5 \\
\hline
\end{tabular}

The baked bread had a good volumetric yield (more than $400 \mathrm{~cm}^{3} / 100 \mathrm{~g}$ of flour), satisfactory and good organoleptic evaluation (Table 8). The crumb of the analyzed samples was with good (G-1, G-2) elasticity, as for the samples (G-3, G-4) - satisfactory elasticity, slightly creasing. The porosity of all samples is small, uneven, thick-walled along the pore walls and was about $80 \%$ for samples (G-1, G-2, G-3), for sample (G-4) this figure was $74 \%$.

The taste is peculiar; the experimental samples (G-2, G-4) had a flax aftertaste, which corresponded to bread with the addition of flax flour. Sample (G-3) had a bitter aftertaste. No crunch or crunchiness was found. Overall, the breads had positive ratings, both in appearance and in crumb.

\section{Conclusion}

In order to increase the use of raw materials and expand the bread range through the development of grain products for the production of food for general, dietary and prophylactic purposes on the basis of poly-grain mixtures, the following points have been developed: a methodology for managing the milling and cereal properties of grain raw materials during its processing to obtain food products on a grain basis given composition and properties; the possibility of joint grinding of wheatflax mixture to obtain flour enriched with essential fatty acids (EFA) $\infty-3$ (Linolenic acid) and-6 (Linoleic acid) is shown; determined some physical and chemical characteristics of wheat flour enriched with EFA; the features of the baking and rheological properties of wheat flour dough enriched with EFA were revealed, the possibility of using not only wheat grain, but also its processed products (cereals) in a mixture with flax to obtain flour enriched with PUFA, was determined, the terms of safe storage of wheat-flax flour were determined. 


\section{References}

1. V. Vassiliev, F. Magni, S. Chernishev, V. Kostege, Impact of the $3 \mathrm{~d}$ flow effects on the silo combustor thermal state, in Proc. of the ASME Turbo Expo Cер., 881-890 (2012)

2. M.B. Toffolo, E. Boaretto, M.A.S. Martin, D.M. Master, Microarchaeology of a grain silo: insights into stratigraphy, chronology and food storage at late bronze age ashkelton, Israel J. of Archaeolog. Sci., 177-188 (2018)

3. M.R. Bonner, M.C.R. Alavanja, Pesticides, human health, and food security, Food and Energy Security, 6(3), 89-93 (2017)

4. W.J. Davies, J.M. Ribaut, Stress resilience in crop plants: Strategic thinking to address local food production problems, Food and Energy Security, 6(1), 12-18 (2017)

5. C. Pollock, Sustainable farming: Chasing a mirage? Food and Energy Security, 5(4), 205-209 (2016)

6. B.H. Cervelin, D. Conti, M.A. Diniz-Ehrhardt, J.M. Martínez, A computer model for particle-like simulation in broiler houses, Computers and Electron. in Agricult., 1-14, (2017)

7. M.J. Oates, A. Ruiz-Canales, M. Ferrández-Villena, A.F. López, A low cost sunlight analyser and data logger measuring radiation, Computers and Electron. in Agricult., 38-48 (2017)

8. C. Gilmore, M. Asefi, J. LoVetri, J. Paliwal, Industrial scale electromagnetic grain bin monitoring, Computers and Electron. in Agricult., 210-220 (2017)

9. P.J. García Nieto, E. García-Gonzalo, J. Bové, M. Duran-Ros, J. Puig-Bargués, Modeling pressure drop produced by different filtering media in microirrigation sand filters using the hybrid ABCMARS-based approach, MLP neural network and
M5 model tree, Computers and Electron. in Agricult., 65-74 (2017)

10. Y. Huang, C. Li, Real-time monitoring system for paddy environmental information based on DC powerline communication technology, Computers and Electron. in Agricult., 51-62 (2017)

11. G.D. Stone, D. Glover, Disembedding grain: Golden Rice, the Green Revolution, and heirloom seeds in the Philippines, Agricult. and Human Values, 87102 (2017)

12. M. Bhatta, V. Belamkar, P.S. Baenziger, A. Morgounov, Genome-wide association study reveals novel genomic regions for grain yield and yield-related traits in drought-stressed synthetic hexaploid wheat, Int. J. of Molecular Sci., 19(10) (2018)

13. I. Kechkin, V. Ermolaev, A. Romanenko, M. Ivanov, E. Gurkovskaya, Dependence of fat acidity value on wheat grain storage conditions, in: International Conference on Food Industry, Economy and Security, 34-39 (2020)

14. I. Kechkin, V. Ermolaev, A. Romanenko, V. Tarakanova, K. Buzetti, Management of air flows inside steel silo during grain storage, in: International Conference on Food Industry, Economy and Security, 22-25 (2020)

15. X. Li, X. Xie, C.H. Zhang, S. Zhen, W. Jia, Drying Technology, 283-293 (2018)

16. B. Sritongtae, K. Duangmal, M.R.A. Morgan, International Journal of Food Science and Technology, 1710-1721 (2020)

17. V.S.O. Farias, L.F. Araujo, W.P. Silva, C.M.R. Franco, P.I.O. Rocha, A.F.S. Junior, JP Journal of Heat and Mass Transfer, 409-432 (2020)

18. O. Alves-Filho, Chemical Engineering Transactions, 145-150 (2020) 